\title{
Recommended Management of Hypertensive Patients with Diabetes for Renin-Angiotensin System (RAS) Inhibitors
}

Bando $\mathrm{H}^{1,2^{*}}$

${ }^{1}$ Medical Research/Tokushima University, Tokushima, Japan

${ }^{2}$ Japan Low Carbohydrate Diet Promotion Association (JLCDPA), Kyoto, Japan

Corresponding Author: Hiroshi BANDO, MD. PhD, FACP

Address: Medical Research/Tokushima University, Nakashowa 1-61, Tokushima 770-0943, Japan; Tel: +81-90-31872485; Fax: +81-88-603-1030; E-mail: pianomed@bronze.ocn.ne.jp

Received date: 05 April 2020; Accepted date: 10 April 2020; Published date: 16 April 2020

Citation: Bando H. Recommended Management of Hypertensive Patients with Diabetes for Renin-Angiotensin System (RAS) Inhibitors. Diab Res Open Access. 2020 Apr 16;2(1):4-8.

Copyright (C) 2020 Bando H. This is an open-access article distributed under the Creative Commons Attribution License, which permits unrestricted use, distribution, and reproduction in any medium, provided the original work is properly cited.

\section{Abstract}

Currently, major categories of antihypertensive agents include diuretics, beta-blockers, calcium channel blockers (CCBs), renin-angiotensin system (RAS) inhibitors [angiotensin converting enzyme (ACE) inhibitors and angiotensin receptor blockers (ARB)]. Among them, RAS (ACE inhibitors and ARB) would be recommended to be a first-line treatment when providing antihypertensive agents for hypertensive patients with diabetes, cardiovascular disease, and impaired renal function. Randomized controlled trials (RCT) of RAS inhibitors compared with other antihypertensive showed a rather lower relative risk (RR). They are all-cause death (RR 0.95), cardiovascular death ( $R R$ - o.84), incidence of cardiovascular disease (RR - 0.93), and incidence of renal dysfunction (RR - 0.91).

\section{Keywords}

Hypertension; Diabetes Mellitus; Renin-Angiotensin System (RAS) Inhibitors; Angiotensin-Converting Enzyme (ACE) Inhibitors; Angiotensin Receptor Blockers (ARB)

\section{Abbreviations}

RAS: Renin-Angiotensin System; ACE: Angiotensin-Converting Enzyme; ARB: Angiotensin Receptor Blocker; CCB: Calcium Channel Blocker; ACC/AHA: American College of Cardiology/American Heart Association; ESC/ESH: European Society of Cardiology and European Society of Hypertension

Hypertension is widely prevalent worldwide. It has been an important disease to cause death and disability from stroke and cardiovascular disease (CVD) worldwide [1]. According to the 2017 American College of Cardiology (ACC)/American Heart Association (AHA) clinical practice guidelines on hypertension, patient number with diagnosed and undetected hypertension is markedly increasing [2].
Results of the SPRINT (Systolic Blood Pressure Intervention Trial) data showed that intensively controlled blood pressure could significantly reduce mortality and CVD events [3]. There has been a report of the National Heart, Lung, and Blood Institute Working Group on Hypertension [4].

Consequently, adequate treatment for hypertension 
can reduce cardiovascular mortality [5]. Currently, major categories of antihypertensive agents include diuretics, beta-blockers, calcium channel blockers (CCBs), renin-angiotensin system (RAS) inhibitors [angiotensin converting enzyme (ACE) inhibitors and angiotensin receptor blockers (ARB)].

For initial therapy for hypertension, beta-blockers have been prevalent since the 196os. Due to a systematic review, beta-blockers showed significantly reduced stroke and cardiovascular events. However, they did not reduce congestive heart disease and allcause mortality [6]. Among them, the clinical effect of beta-blockers was less than low-dose thiazides, ACE inhibitors, and CCB [6]. According to the Cochrane study, dual alpha and beta-blockers lowered BP for 6 / $4 \mathrm{mmHg}$ on average. Also, this effect was less than that of beta1-selective blockers [7]. Another Cochrane review revealed that beta1-selective blockers have a stronger lowering effect of 10 / 8mmHg. Furthermore, beta1-selective blockers reduced blood pressure (BP) to a greater degree in comparison with dual alpha and beta-blockers [8].

For general information on beta-blockers, propranolol has an affinity for beta1 and beta2 receptors as a non-selective beta-blocker [5]. Among beta-blockers, the most commonly used agent has been atenolol. Atenolol and bisoprolol preferentially interact with beta1 more than beta2 receptors as selective beta-blockers. Carvedilol exhibits affinity for beta1 and alpha receptors as dual alpha and betablocker [5]. There was a report comparing the effect of carvedilol and bisoprolol for patients with heart failure with reduced ejection fraction (HFrEF) [9]. As a result, the prescription of beta-blockers reduced allcause mortality (HR o.59), and two agents had comparable effects.

Secondly, diabetes has been also crucial disease in the world, frequently associated with high blood pressure. For patients with type1 and 2 diabetes mellitus (T1DM and T2DM), hypertension has been a very common complication $[10,11]$. To continue good BP control can bring effect for reducing the macrovascular and microvascular complications $[12,13]$. According to the guideline of the United States and Europe, the degree of reducing BP would become the main determinant of lowering cardiovascular risk in comparison with the administration of $[2,14]$.

Among their guidelines, some antihypertensive agents have been considered to decrease cardiovascular events for diabetic patients, including thiazide-like diuretics, CCBs, ACE inhibitors, ARBs. ACE inhibitors and ARBs belong to the group of RAS inhibitors, which have been provided as first-line therapy for hypertensive diabetic patients.

There was a meta-analysis of randomized controlled trials to study the efficacy among RAS inhibitors and another antihypertensive [15]. From a total 16 trials with 35,052 patients, the result showed a rather lower relative risk (RR). They are all-cause death (RR 0.95), cardiovascular death (RR o.84), the incidence of cardiovascular disease (RR 0.93), and incidence of renal dysfunction (RR o.91), while there were no significant differences [15].

RAS inhibitors mainly include ACE inhibitors and ARBs and show the beneficial effect of reducing urinary albumin [16]. The presence of albuminuria has been estimated to be a risk factor for cardiovascular events [17]. Then, RAS inhibitors have been primarily the first-line antihypertensive for diabetic patients, because they have also improved insulin-resistant effect and Renoprotective effect [18]. From mentioned above, RAS inhibitors are recommended to provide patients who are diabetic hypertensive, associated with some renal function impairment such as proteinuria or microalbuminuria.

For hypertensive diabetic patients, there are reports of a meta-analysis of trials that compare RAS inhibitors and other category agents [19,20]. From the results, RAS inhibitors showed no better than other agents as a first-line antihypertensive agent for several markers. They include the degree of reducing cardiovascular death, all-cause death, the incidence of renal dysfunction and the incidence of cardiovascular disease. Their summarized effects were suggested to show lower risks, whereas statistically significant difference was not found $[17,20]$. These results were consistent with those of relevant major known 
Citation: Bando H. Recommended Management of Hypertensive Patients with Diabetes for Renin-Angiotensin System (RAS) Inhibitors. Diab Res Open Access. 2020 Apr 16;2(1):4-8.

\section{Editorial}

guidelines $[2,13,14]$.

There are some guidelines for adequate treatment for hypertensive patients with diabetes. Among them, RAS inhibitors have been recommended as first-line treatment $[17,18]$. From a statistic point of view, some cases show significant differences in certain research protocols. The probable factors would be in the following: i) comparison of RAS inhibitors with CCBs or with beta-blockers or diuretics, ii) proposed target blood pressure, iii) enough effect of assigned agents, iv) follow-up period of the protocol in the trials, v) included or excluded for patients with impaired renal function and vi) positive or negative for the history of the cardiovascular accident. Generally, the recommendation was almost based on the expected protective efficacy of RAS inhibitors over placebo medicine from diabetic nephropathy $[17,18]$.

When a multidrug regimen can be used to achieve for the target BP, the administration of a RAS inhibitor to the protocol may be successful [20]. According to the research protocol, a protective effect for nephropathy of each agent would be considered $[20,21]$. Recently, the updated guidelines by the European Society of Cardiology and European Society of Hypertension (ESC/ESH) 2018 have included such clinical judgments [21].

For hypertensive patients with diabetes and albuminuria, the guidelines or statements showed the recommendation including ACE inhibitors or ARBs for the initial treatment of risk reduction against the progression of renal disease [21]. There has been some evidence for the judgment by some guidelines such as the 2017 American Hospital Association/American College of Cardiology Guidelines. However, the relevant recommendation has been as Class IIb, which means a weak degree $[2,21]$.

In summary, recent topics concerning the treatment for hypertensive patients with diabetes and its complications would be described. As an antihypertensive agent, RAS agents such as ACE inhibitors and ARBs have been recommended for expecting the preventive effects. This article may hopefully become some reference for clinical practice and research.

\section{Acknowledgment}

None

\section{COI}

None

\section{Funding}

None

\section{References}

[1] Forouzanfar MH, Liu P, Roth GA, Ng M, Biryukov S, Marczak L, Alexander L, Estep K, Hassen Abate K, Akinyemiju TF, Ali R, Alvis-Guzman N, Azzopardi P, Banerjee A, Bärnighausen T, Basu A, Bekele T, Bennett DA, Biadgilign S, Catalá-López F, Feigin VL, Fernandes JC, Fischer F, Gebru AA, Gona P, Gupta R, Hankey GJ, Jonas JB, Judd SE, Khang YH, Khosravi A, Kim YJ, Kimokoti RW, Kokubo Y, Kolte D, Lopez A, Lotufo PA, Malekzadeh R, Melaku YA, Mensah GA, Misganaw A, Mokdad AH, Moran AE, Nawaz H, Neal B, Ngalesoni FN, Ohkubo T, Pourmalek F, Rafay A, Rai RK, RojasRueda D, Sampson UK, Santos IS, Sawhney M, Schutte AE, Sepanlou SG, Shifa GT, Shiue I, Tedla BA, Thrift AG, Tonelli M, Truelsen T, Tsilimparis N, Ukwaja KN, Uthman OA, Vasankari T, Venketasubramanian N, Vlassov VV, Vos T, Westerman R, Yan LL, Yano Y, Yonemoto N, Zaki ME, Murray CJ. Global Burden of Hypertension and Systolic Blood Pressure of at Least 110 to $115 \mathrm{~mm} \mathrm{Hg}$, 1990-2015. JAMA. 2017 Jan 10;317(2):165-82. [PMID: 28097354]

[2] Whelton PK, Carey RM, Aronow WS, Casey DE Jr, Collins KJ, Dennison Himmelfarb C, DePalma SM, Gidding S, Jamerson KA, Jones DW, MacLaughlin EJ, Muntner P, Ovbiagele B, Smith SC Jr, Spencer CC, Stafford RS, Taler SJ, Thomas RJ, Williams KA Sr, $\begin{array}{llll}\text { Williamson JD, Wright JT Jr. } 2017 & \end{array}$ ACC/AHA/AAPA/ABC/ACPM/AGS/APhA/ASH/ASPC/ NMA/PCNA Guideline for the Prevention, Detection, Evaluation, and Management of High Blood Pressure in Adults: Executive Summary: A Report of the American College of Cardiology/American Heart Association Task Force on Clinical Practice Guidelines. 
Citation: Bando H. Recommended Management of Hypertensive Patients with Diabetes for Renin-Angiotensin System (RAS) Inhibitors. Diab Res Open Access. 2020 Apr 16;2(1):4-8.

Hypertension. 2018 Jun;71(6):1269-24. [PMID: 29133354]

[3] SPRINT Research Group, Wright JT Jr, Williamson JD, Whelton PK, Snyder JK, Sink KM, Rocco MV, Reboussin DM, Rahman M, Oparil S, Lewis CE, Kimmel PL, Johnson KC, Goff DC Jr, Fine LJ, Cutler JA, Cushman WC, Cheung AK, Ambrosius WT. A Randomized Trial of Intensive versus Standard BloodPressure Control. N Engl J Med. 2015 Nov 26;373(22):2103-16. [PMID: 26551272]

[4] Sigmund CD, Carey RM, Appel LJ, Arnett DK, Bosworth HB, Cushman WC, Galis ZS, Green Parker M, Hall JE, Harrison DG, McDonough AA, Nicastro HL, Oparil S, Osborn JW, Raizada MK, Wright JD, Oh YS. Report of the National Heart, Lung, and Blood Institute Working Group on Hypertension: Barriers to Translation. Hypertension. 2020 Apr;75(4):902-17. [PMID: 32063061]

[5] Kishi T, Fujii E. Carvedilol and bisoprolol as initial therapy for adult hypertension without compelling indications. Hypertens Res. 2019 Apr;42(4):496-503. [PMID: 30948819]

[6] Wright JM, Musini VM, Gill R. First-line drugs for hypertension. Cochrane Database Syst Rev. 2018 Apr 18;4:CDoo1841. [PMID: 29667175]

[7] Wong GW, Laugerotte A, Wright JM. Blood pressure lowering efficacy of dual alpha and beta blockers for primary hypertension. Cochrane Database Syst Rev. 2015 Aug 26;(8):CDoo7449. [PMID: 26306578]

[8] Wiysonge CS, Bradley HA, Volmink J, Mayosi BM, Opie LH. Beta-blockers for hypertension. Cochrane Database Syst Rev. 2017 Jan 20;1:CDoo2003. [PMID: 28107561]

[9] Choi KH, Lee GY, Choi JO, Jeon ES, Lee HY, Lee SE, Kim JJ, Chae SC, Baek SH, Kang SM, Choi DJ, Yoo BS, Kim KH, Cho MC, Park HY, Oh BH. The mortality benefit of carvedilol versus bisoprolol in patients with heart failure with reduced ejection fraction. Korean J Intern Med. 2019 Sep;34(5):1030-39. [PMID: 30317846]

[10] Espinola-Klein C, Weisser G, Jagodzinski A, Savvidis S, Warnholtz A, Ostad MA, Gori T, Munzel T. $\beta$-Blockers in patients with intermittent claudication and arterial hypertension: results from the nebivolol or metoprolol in arterial occlusive disease trial. Hypertension. 2011 Aug;58(2):148-54. [PMID:
[P
21646599]

[11] Wijkman M, Länne T, Engvall J, Lindström T, Ostgren CJ, Nystrom FH. Masked nocturnal hypertension--a novel marker of risk in type 2 diabetes. Diabetologia. 2009 Jul;52(7):1258-64. [PMID: 19396423]

[12] Emdin CA, Rahimi K, Neal B, Callender T, Perkovic V, Patel A. Blood pressure lowering in type 2 diabetes: a systematic review and meta-analysis. JAMA. 2015 Feb 10;313(6):603-15. [PMID: 25668264]

[13] Mancia G, Fagard R, Narkiewicz K, Redón J, Zanchetti A, Böhm M, Christiaens T, Cifkova R, De Backer G, Dominiczak A, Galderisi M, Grobbee DE, Jaarsma T, Kirchhof P, Kjeldsen SE, Laurent S, Manolis AJ, Nilsson PM, Ruilope LM, Schmieder RE, Sirnes PA, Sleight P, Viigimaa M, Waeber B, Zannad F; Task Force Members. 2013 ESH/ESC Guidelines for the management of arterial hypertension: the Task Force for the management of arterial hypertension of the European Society of Hypertension (ESH) and of the European Society of Cardiology (ESC). J Hypertens. 2013 Jul;31(7):1281-57. [PMID: 23817082]

[14] American Diabetes Association. Standards of Medical Care in Diabetes-2018 Abridged for Primary Care Providers. Clin Diabetes. 2018 Jan;36(1):14-37. [PMID: 29382975]

[15] Kunimura A, Himuro N, Fujiyoshi A, Segawa H, Ohnishi H, Saitoh S. The effects of renin-angiotensin system inhibitors on mortality, cardiovascular events, and renal events in hypertensive patients with diabetes: a systematic review and meta-analysis of randomized controlled trials. Hypertens Res. 2019 May;42(5):669-8o. [PMID: 30948835]

[16] Schmieder RE, Hilgers KF, Schlaich MP, Schmidt BM. Renin-angiotensin system and cardiovascular risk. Lancet. 2007 Apr 7;369(9568):1208-19. [PMID: 17416265]

[17] Shimamoto K, Ando K, Fujita T, Hasebe N, Higaki J, Horiuchi M, Imai Y, Imaizumi T, Ishimitsu T, Ito M, Ito S, Itoh $\mathrm{H}$, Iwao $\mathrm{H}$, Kai H, Kario K, Kashihara N, Kawano Y, Kim-Mitsuyama S, Kimura G, Kohara K, Komuro I, Kumagai H, Matsuura H, Miura K, Morishita R, Naruse M, Node K, Ohya Y, Rakugi H, Saito I, Saitoh S, Shimada K, Shimosawa T, Suzuki H, Tamura K, Tanahashi N, Tsuchihashi T, Uchiyama M, Ueda S, Umemura S; Japanese Society of Hypertension Committee for Guidelines for the Management of 
Citation: Bando H. Recommended Management of Hypertensive Patients with Diabetes for Renin-Angiotensin System (RAS) Inhibitors. Diab Res Open Access. 2020 Apr 16;2(1):4-8.

\section{Editorial}

Hypertension. The Japanese Society of Hypertension Guidelines for the Management of Hypertension (JSH 2014). Hypertens Res. 2014 Apr;37(4):253-90. [PMID: 24705419]

[18] Haneda M, Noda M, Origasa H, Noto H, Yabe D, Fujita Y, Goto A, Kondo T, Araki E. Japanese Clinical Practice Guideline for Diabetes 2016. J Diabetes Investig. 2018 Mar 26. [PMID: 29582574]

[19] Bangalore S, Fakheri R, Toklu B, Messerli FH. Diabetes mellitus as a compelling indication for use of renin angiotensin system blockers: systematic review and meta-analysis of randomized trials. BMJ. 2016 Mar 14;352:i1525. [PMID: 26975479]

[20] Palmer SC, Mavridis D, Navarese E, Craig JC, Tonelli M, Salanti G, Wiebe N, Ruospo M, Wheeler DC, Strippoli GF. Comparative efficacy and safety of blood pressure-lowering agents in adults with diabetes and kidney disease: a network meta-analysis. Lancet. 2015 May 23;385(9982):2047-56. [PMID: 260o9228]

[21] Williams B, Mancia G, Spiering W, Agabiti Rosei E, Azizi M, Burnier M, Clement DL, Coca A, de Simone G, Dominiczak A, Kahan T, Mahfoud F, Redon J, Ruilope L, Zanchetti A, Kerins M, Kjeldsen SE, Kreutz R, Laurent S, Lip GYH, McManus R, Narkiewicz K, Ruschitzka F, Schmieder RE, Shlyakhto E, Tsioufis C, Aboyans V, Desormais I; ESC Scientific Document Group. 2018 ESC/ESH Guidelines for the management of arterial hypertension. Eur Heart J. 2018 Sep 1;39(33):3021-104. [PMID: 30165516]

Keywords: Hypertension; Diabetes Mellitus; Renin-Angiotensin System (RAS) Inhibitors; Angiotensin-Converting Enzyme (ACE) Inhibitors; Angiotensin Receptor Blockers (ARB) 